Report No. BMI- 1338

UC-25 Metallurgy and Ceramics (TID-4500. 14th Eid)

Contract No. $W-7405-e n g-92$

THE EFFECT OF IMPURITIES ON IRON-CHROMIUM-YTTRIUM ALLOYS

by

Roy W. Endebrock

Walston Chubb

Ellis L. Foster

Ronald F. Dickerson

April 27, 1959

BAT TELLE MEMORIAL INSTITUTE

505 King Avenue

Columbus 1. Ohio 


\section{DISCLAIMER}

This report was prepared as an account of work sponsored by an agency of the United States Government. Neither the United States Government nor any agency Thereof, nor any of their employees, makes any warranty, express or implied, or assumes any legal liability or responsibility for the accuracy, completeness, or usefulness of any information, apparatus, product, or process disclosed, or represents that its use would not infringe privately owned rights. Reference herein to any specific commercial product, process, or service by trade name, trademark, manufacturer, or otherwise does not necessarily constitute or imply its endorsement, recommendation, or favoring by the United States Government or any agency thereof. The views and opinions of authors expressed herein do not necessarily state or reflect those of the United States Government or any agency thereof. 


\section{DISCLAIMER}

Portions of this document may be illegible in electronic image products. Images are produced from the best available original document. 
TABLE OF CONTENTS

$\underline{\text { Page }}$

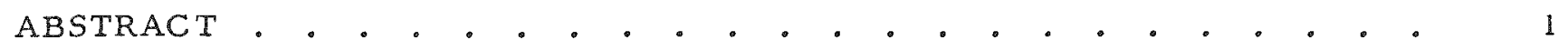

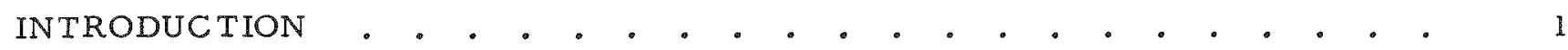

EXPERIMENTAL WORK . • . . . . . . . . . . . . . . . . . 2

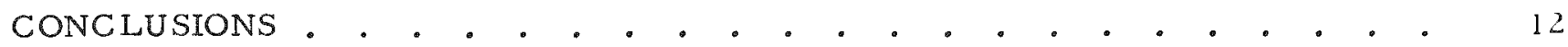




\title{
THE EFFECT OF IMPURITIES ON IRON-CHROMIUM-YTTRIUM ALLOYS
}

\author{
Roy W. Endebrock, Walston Chubb, Ellis L. Foster, \\ and Ronald F. Dickerson
}

\begin{abstract}
A study has been made of the effect of carbon, manganese, oxygen, palladium, and sulfur on the structure and fabricability of iron-35 w/o chromium-1 $w / 0$ yttrium alloy. Using a vacuum-induction melting technique each of the additives except oxygen us introduced to $1-16$ remelts of a single 15-lb master alloy. The master alloy and remelts were made under similar melting, pouring, and casting conditions. Oxygen was introduced as $\mathrm{Fe}_{2} \mathrm{O}_{3}$ by inert-electrode arc melting to avoid extraneous, uncontrolled contamination stemming from crucible contact. Photomicrographs were prepared of as-cast metal illustrating structural variations. Ingots obtained were fabricated to 0.050-in. sheet at $2000 \mathrm{~F}$ to compare fabrication characteristics with those of the control ingot containing no additives. As a qualitalive measure of metal soundness and ductility, a portion of each of the 0.050-in. sheets u'as further reduced at room temperature to 3-mil foil.
\end{abstract}

Turing melting at 2900 to $3000 \mathrm{~F}$ under controlled conditions, the amount of yttrium present in the charge was reduced roughly 50 per cent by reaction with the alumina crucible. Sulfide, added as FeS, and oxide additions also lowered the amount of ytirium retained in ingots. The maximum amount of sulfur retained in an alloy of nominal composition iron- $35 \mathrm{w} / \mathrm{o}$ chromium-1 $w / 0$ yttrium-500 ppm sulfur was found to be about $80 \mathrm{ppm}$, and an alloy containing this amount of sulfur seemed to show slightly improved fabrication characteristics. None of the impurities investigated affected the fabrication characteristics or the quality of the finished product sufficiently to be considered detrimental from this point of view.

\section{INTRODUCTION}

Iron-chromium alloys containing about $1 \mathrm{w} / 0$ yttrium have demonstrated remarkable resistance to oxidation at $2300 \mathrm{~F}$. These alloys are relatively undeveloped, however, and research is required to provide additional knowledge that will assure reproducible casting, fabrication, and corrosion characteristics of the alloy. This report describes a portion of this developmental effort and deals with a study of the effect of carbon, manganese, oxygen, palladium, and sulfur on the structure and fabrication characteristics of the basic alloy, iron $-35 \mathrm{w} / 0 \mathrm{chromium}-1 \mathrm{w} / 0$ yttrium.

The impurities, carbon, oxygen, and sulfur are often found in ingots and are believed to derive from the charge materials or in some cases from crucibles, molds, and furnace atmospheres. Sulfur usually affects the fabricability of alloys adversely, and manganese is added in an attempt to counteract any such effect. Palladium has been reported to allow the use of higher amounts of chromium in the basic alloy. Increasing chromium content at the expense of iron has been reported to improve hightemperature strength characteristics. 


\section{EXPERIMENTAL WORK}

To circumvent the problem of reproducibility of the basic alloy a 15 -lb master alloy, prepared from high-purity materials by vacuum-induction melting in an alumina crucible, was used as the base to which the various impurities were added separately. The master alloy had the composition ires $-34.4 \mathrm{w} / 0$ chromium $-2.0 \mathrm{w} / 0$ yttrium. A spectrographic analysis of this alloy showed no palladium to be present and less than $50 \mathrm{ppm}$ of either manganese or aluminum. Sulfur and carbon contents were less than $30 \mathrm{ppm}$. A vacuum-fusion analysis showed the oxygen content to be $23 \mathrm{ppm}$ and the hydrogen content to be $0.2 \mathrm{ppm}$. The as-cast structure of the master alloy (Figure 1) showed a well-distributed network of second-phase material, presumed to be a eutectic mixture of $\mathrm{YFe}_{5}$ and alpha iron-chromium surrounding clean dendritic alpha ironchromium solid solution. The master alloy was reduced to $1 / 16-i n$. sheet of excellent quality by forging and rolling at $2000 \mathrm{~F}$. This sheet was cleaned by vapor blasting and cut up for use as remelt stock.

One-pound portions of the master alloy were induction melted in alumina crucibles in a vacuum furnace. Manganese and palladium were added as pure ruetals, sulfur as iron sulfide, and carbon as iron carbide. Each additive was thoroughly mixed with the melt by induction stirring. Each melt was made in a new alumina crucible and was held molten at a temperature of $2850 \mathrm{~F}$ and under a pressure of less than $2 \times 10^{-3} \mathrm{~mm}$ of mercury. After holding each metal charge at $2850 \mathrm{~F}$ for $10 \mathrm{~min}$ the desired impurity was added, and the melt was stirred and poured within a 2 -min period into a 1-1b-capacity Zirconite mold (or, as noted, into a copper mold).

Oxygen was added to the base alloy as a known amount of $\mathrm{Fe}_{2} \mathrm{O}_{3}$ to a charge of the master alloy, and the entire charge was arc melted. In this way, contact of this alloy with an alumina crucible was prevented and extraneous oxide reactions were avoided. A l-1b control ingot (no impurities added) was made by remelting a portion of the master alloy in a new alumina crucible. Adjustments were made to bring the chromium composition of the control as well as that of all other remelts to $35 \mathrm{w} / 0$. Analysis revealed that the yttrium content of the control alloy after remelting had decreased from $2.0 \mathrm{w} / 0$ to $1.17 \mathrm{w} / 0$. Oxygen and hydrogen contents were found to be 11 ppm and $0.5 \mathrm{ppm}$, respectively. The as-cast structure of the control (Figure 2) was very similar to that of the original master-alloy casting except for some refinement in structure possibly caused by the increased cooling rate of the smaller ingot. Metallographic examinations were made of specimens cut from each ingot. A 10 per cent aqueous solution of oxalic acid was used for electrolytic etching. Pertinent analytical results obtained on all the ingots are shown in Table 1.

As mentioned earlier, the effect of manganese was of interest because of its possible use as a counteractant for sulfur contamination in the alloy. Consequently, two impurity conditions were considered: one in which the effect of manganese would be treated separately, and the other in which manganese would be introduced to neutralize the effects of sulfur already present in the alloy. Although admittedly somewhat arbitrary, the amount of manganese used was based on a "rule of thumb" steel practice of adding five parts of manganese for each part of sulfur present. On the assumption that $500 \mathrm{ppm}$ of sulfur could be present as an impurity, $2500 \mathrm{ppm}$ of manganese was considered a sufficient amount for the purpose of this experiment. This amount of manganese, added separately (Figure 3), or in conjunction with sulfur (Figure 4), appeared to have little effect on the as-cast structure or on the fabrication characteristics of the alloy. 


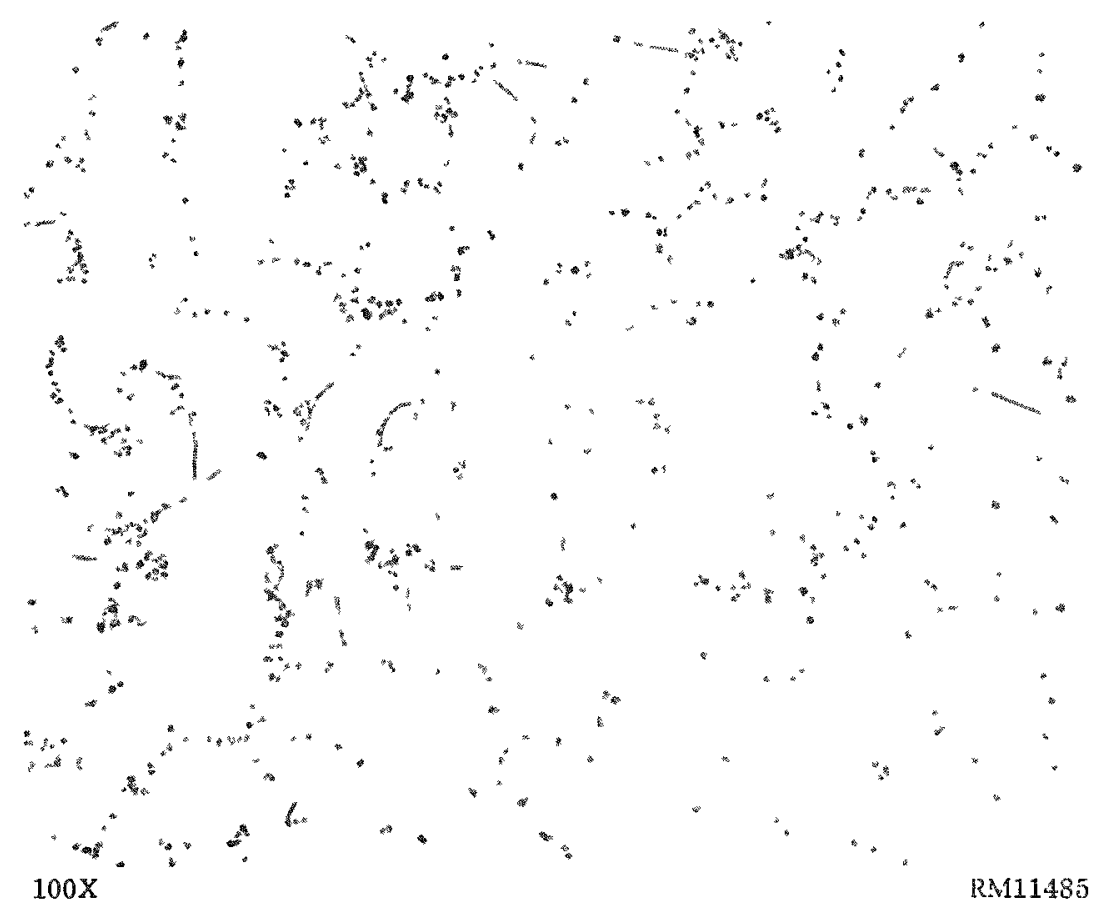

FIGURE 1. AS-CAST SECTION OF MASTER ALLOY, NOMUNALLY IRON-35 w/o CHROMIUM-2 W/O YTTRIUM

Second-phase material is presumed to be a eutectic mixture of $\mathrm{YFe}_{5}$ and alpha iron-chromium.

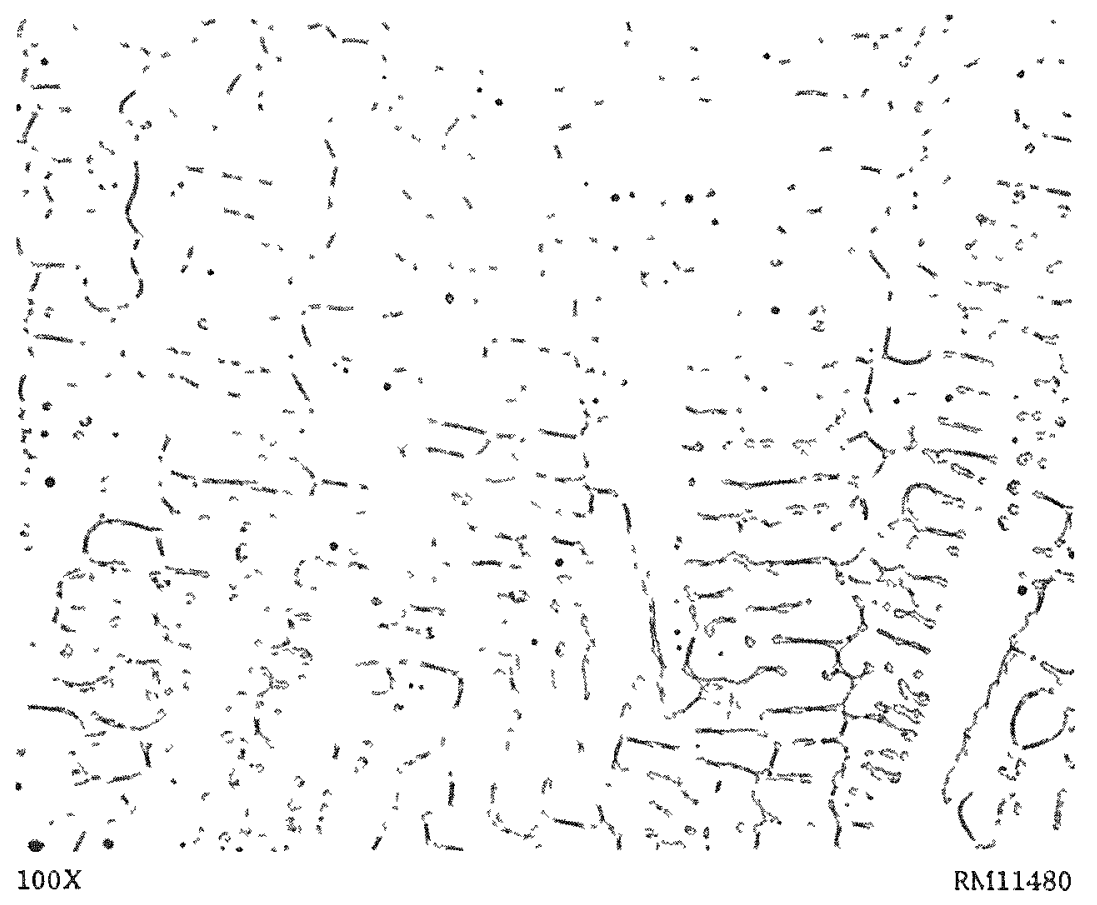

FIGURE 2. AS-CAST SECTION OF CONTROL ALLOY

Alloy composition: iron $-35 \mathrm{w} / \mathrm{o}$ chromium $-1.2 \mathrm{w} / \mathrm{o}$ yttrium. 
TABLE 1. ANALYSES OF INGOTS(a)

\begin{tabular}{|c|c|c|c|c|c|c|}
\hline Impuriry Addıtion & $\begin{array}{l}\text { Amount of } \\
\text { Additive } \\
\text { Charged, w/o }\end{array}$ & $\begin{array}{c}\text { Ingot } \\
\text { Weight, lb }\end{array}$ & $\begin{array}{c}\text { Type of } \\
\text { Melt }\end{array}$ & $\begin{array}{c}\text { Ytriium } \\
\text { Analysis, w/o }\end{array}$ & $\begin{array}{c}\text { Additive } \\
\text { Analysis, wio }\end{array}$ & $\begin{array}{c}\text { Total Number } \\
\text { of Remelts }\end{array}$ \\
\hline None, master alloy & - & 15 & $\begin{array}{l}\text { Vacuum } \\
\text { induction }\end{array}$ & 2.0 & $-\infty$ & $\cdots$ \\
\hline None, control alloy & -- & 1 & Dirto & 1.17 & -- & 1 \\
\hline Manganese & $0.25 \mathrm{Mn}$ & 1 & Ditto & 1. 12 & $0.23 \mathrm{Mn}$ & 1 \\
\hline Iron sulfide No. 1 & $0.05 \mathrm{~S}$ & 2 & Ditto & 0.94 & $0.008 \mathrm{~s}$ & 1 \\
\hline $\begin{array}{l}\text { Iron sulfide and } \\
\text { manganese }\end{array}$ & $\begin{array}{l}0.008 \mathrm{~S} \\
0.25 \mathrm{Mn}\end{array}$ & 1 & Ditro & 0.59 & $\begin{array}{l}0.008 \mathrm{~S} \\
0.19 \mathrm{Mn}\end{array}$ & 2 \\
\hline Iron sulfide No. 2 & $0.25 \mathrm{~S}$ & 1 & Ditto & 0.2 & $0.012 \mathrm{~s}$ & 1 \\
\hline Palladium & $1.0 \mathrm{Pd}$ & 1 & Ditto & 1.02 & $0.83 \mathrm{Pd}$ & 1 \\
\hline Iron carbide & $0.08 \mathrm{C}$ & 1 & Dirto & 1.07 & $0.08 \mathrm{C}$ & 1 \\
\hline Iron oxide & (b) & 0.3 & $\begin{array}{l}\text { Inert-electrode } \\
\text { arc }\end{array}$ & $<0.1$ & 0.120 & 1 \\
\hline None, control alloy & -- & 1 & $\begin{array}{l}\text { Vacuum induc- } \\
\text { tion, chill } \\
\text { cast }\end{array}$ & 1.08 & $-\infty$ & 1 \\
\hline Iron carbide & $0.08 \mathrm{C}$ & 1 & $\begin{array}{l}\text { Vacuum } \\
\text { anduction, } \\
\text { chill cast }\end{array}$ & 1.38 & $0.08 \mathrm{C}$ & 1 \\
\hline
\end{tabular}

(a) Chromium content of alloys varied from 34.4 to $35.1 \mathrm{~W} / \mathrm{o}$.

(b) 110 per cent of the stoichiometric amount necessary to react with the ytrium. 


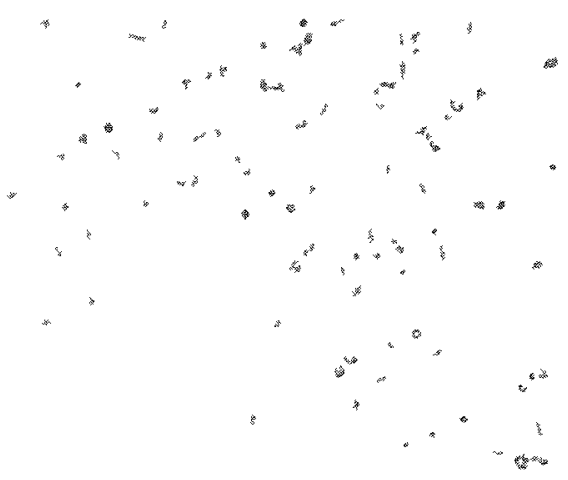$$
-\infty
$$

\begin{abstract}
10 Volume Per Cent Oxalic RM11.182
\end{abstract} Acld, Electrolytu, Etch

FIGURE 3. AS-CAST SECTION OF IRON-35 w/o CHROMIUM - $1.12 \mathrm{w} / 0$ YTTRIUM0.23 W/O MANGANESE ALLOY

The inanganese addition had no observable effect on itructure. A companison can be made with the structure of the control showil in Figure 2.

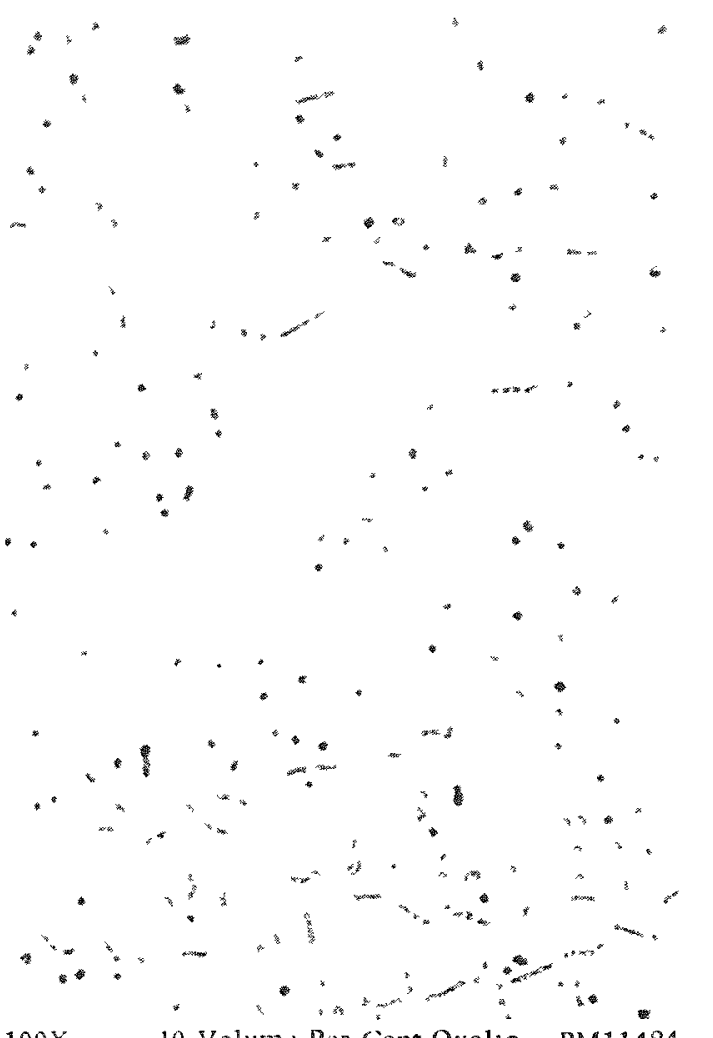

$100 \mathrm{x}$

10 Volume Per Cent Oxalic Acld, Electrolytic Etch

FIGURE 4. AS-CAST SECTION OF INGOT WITH SULFUR AND MANGANLSE ADDITIONS

Alloy composition: iron-34.8 w/o chromium- 0.59 $w / 0$ yttrum-0.19 w/o inanganese $\infty 0.008 \mathrm{w} / 0$ sulfur.

A signuficant reduction of second-phase material occurred through reaction with the alumina crucible wheh contaned the melt.

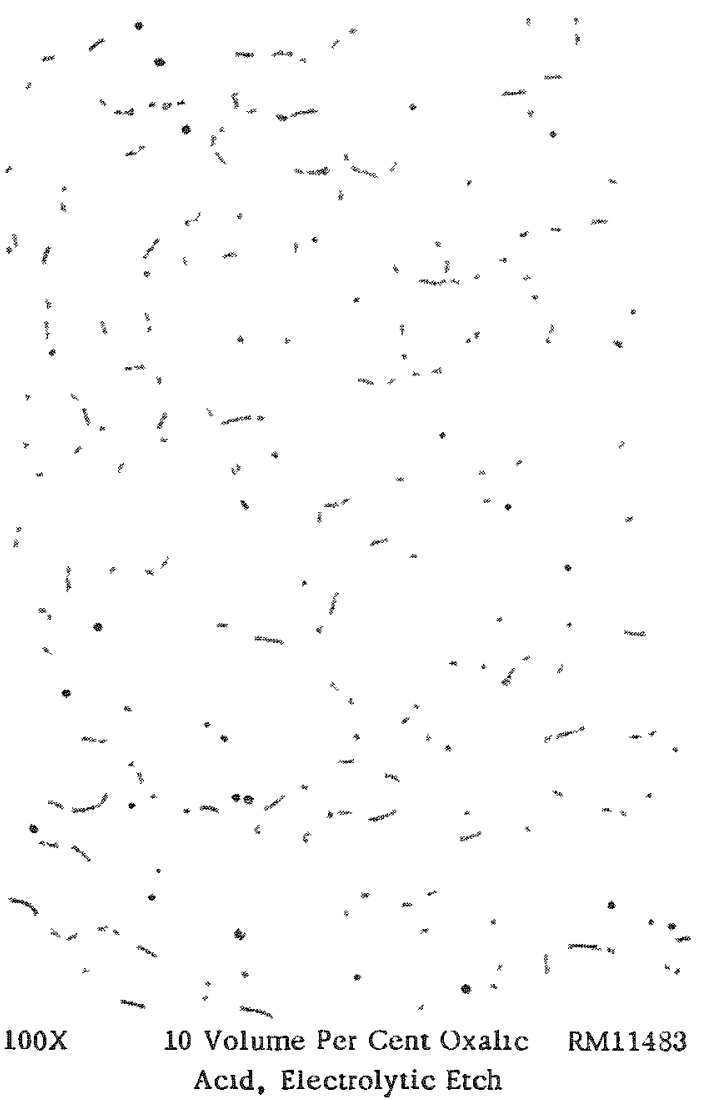

FIGURE 5. AS-CAST SECTION OF INGOT WITII SULFUR ADDITION

Alloy composition: 1ron $-35 \mathrm{w} / 0$ chromum -0.94 w/o yttrium $-0.008 \mathrm{w} / 0$ sulfur.

Only 16 per cent of the amount of sulfur charged to the melt as Fes was retaned by the alloy. 
The sulfur addition was made as FeS, and the charge contained 500 ppm of sulfur. A 2-1b melt was cast and the resulting ingot was cut into two pieces: one portion to be used for a fabrication test and the second to be used as remelt stock to which manganese was to be added. The ingot was found to contain only $80 \mathrm{ppm}$ sulfur or only 16 per cent of the amount charged to the melt. Yttrium content was reduced to $0.94 \mathrm{w} / \mathrm{o}$. The as cast structure, as shown in Figure 5, was essentially the same as that of the control alloy. The remelt of this material with an addition of $0.25 \mathrm{w} / 0$ manganese resulted in an alloy with a composition of iron $-34.8 \mathrm{w} / 0$ chromium $-0.59 \mathrm{w} / 0$ yttrium $-0.008 \mathrm{w} / 0$ sulfur $-0.19 \mathrm{w} / 0$ manganese. It is noteworthy that in remelting the alloy a second time the yttrium content was reduced by about the same order of magnitude as occurred in the case of almost every remelt of master-alloy material. These reductions of yttrium content constitute strong evidence of a crucible surface reaction of roughly the same order of magnitude. The as-cast structure, shown in Figure 5, of the sulfur-manganese alloy was similar to that of the control alloy except for an obvious reduction in secondphase matexial.

A second attempt to introduce sulfur into the base alloy was made by charging five times as much FeS to the melt, 0.25 w/o sulfur. An analysis of the resulting ingot revealed a sulfur content of only $120 \mathrm{ppm}$ and an yttrium content of only $0.2 \mathrm{w} / 0$. This disproportionate loss of yttrium suggests an yttrium-sulfur reaction which removes yttrium from the melt. The loss can be accounted for if the yttrium is assumed to combine with sulfur as YS and is lost from the melt as vapor, dross, or slag. The as cast structure (Figure 6) revealed much larger grains, a reduced amount of grainboundary material $\left(\mathrm{YFe}_{5}\right)$, and a dispersion of unidentified foreign matter in the matrix.

A $1.0 \mathrm{w} / 0$ addition of palladium to a remelt of the master alloy produced an as cast structure similar to that of the control alloy except for the presence of a fine and fairly uniform dispersion of second-phase material in the iron-chromium phase. This particular second-phase material as well as the grain-boundary network etched black in a 10 per cent solution of oxalic acid (Figure 7), whereas in the metallographic etching of all the other alloys the second-phase material, when present, appeared light. This etching behavior suggests the presence of a palladium-yttrium compound perhaps similar to PdAl.

The as-cast structure of an ingot containing 800 ppm carbon (Figure 8) was very similar to that of the control alloy but showed uniformly distributed agglomerations of square platelets in the second phase suggesting graphitic carbon. The iron-chromium phase was exceptionally clean. A duplicate melt containing 800 ppm carbon was cast in a 1 -in.-diameter copper mold rather than in Zirconite to check the effect of an increased cooling rate on structure and fabricability. This resulted in the as-cast structure shown in Figure 9b, which shows practically no precipitated carbon. A macroetched cross section of the ingot (Figure 9a) revealed needlelike columnar grains roughly $1 / 6$ in. long extending inward from the edge. Small equiaxed grains comprised the center of the ingot. The grain size appeared to be smaller than that of a control alloy which was also cast in copper (Figure 10).

The alloy prepared by arc melting was intended to demonstrate the effect of oxygen on the yttrium content of the alloy. Iron oxide, $\mathrm{Fe}_{2} \mathrm{O}_{3}$, was added to the master alloy to the extent of 110 per cent of the stoichiometric amount required to react with all the yttrium present to form $\mathrm{Y}_{2} \mathrm{O}_{3}$. The resulting bar ingot contained less than $0.1 \mathrm{w} / 0$ 


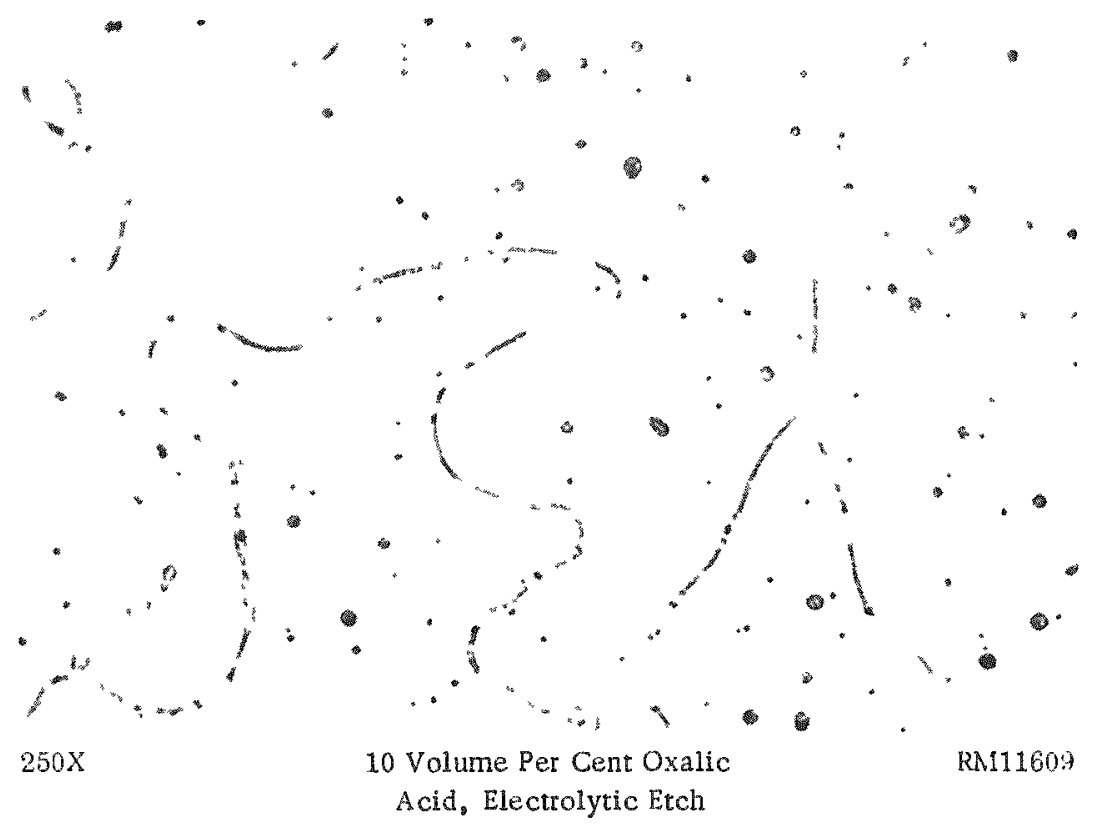

FIGURE 6. AS-CAST SECTION OF INGOT WITH LARGE SULFUR ADDITION

Alloy composition: iron $-35 \mathrm{w} / \mathrm{o}$ chromum $=0.2 \mathrm{w} / \mathrm{o}$ yttrium $-0.012 \mathrm{w} / \mathrm{o}$ sulfur.

Large amounts of sulfur added as Fes to the melt removed essentially all yttrium as dross.

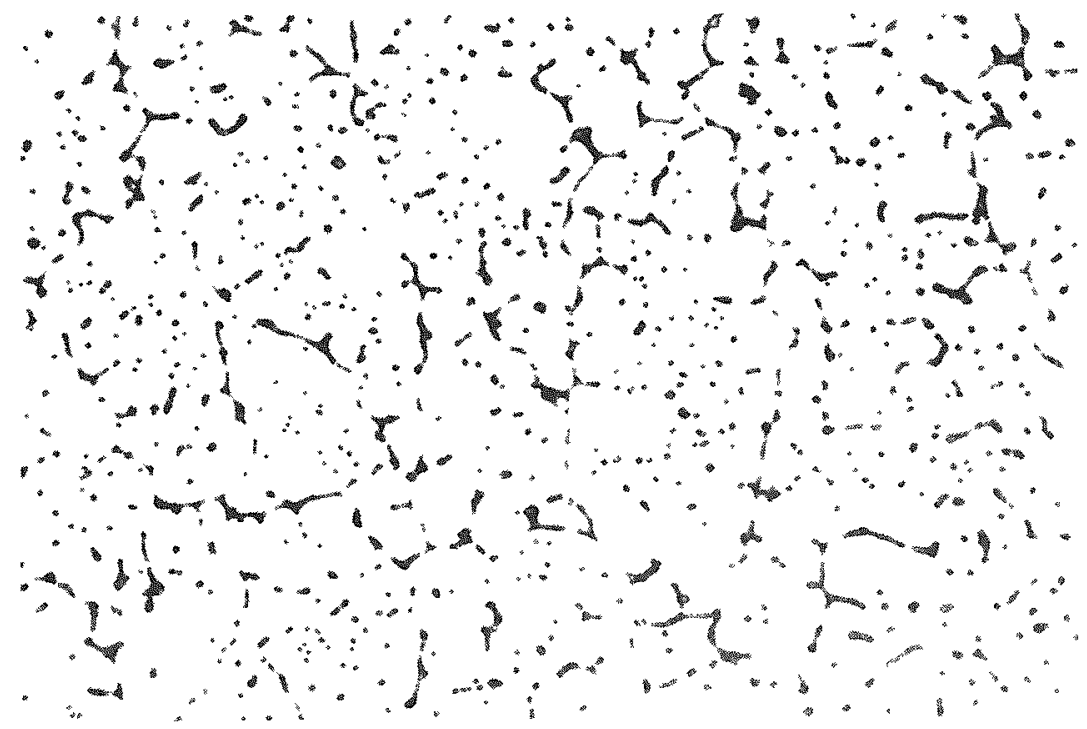

$100 x$

In Volume Per Cent Oxalic

RR.111.61 Acld, Electrolytic Etch

FIGURE 7. AS-CAST SECTION OF INGOT WITH PALLADIUM ADDED

Alloy composition: tron $-35 \mathrm{w} / 0$ chromium $-1.02 \mathrm{w} / 0$ ytrium -0.83 w/o palladium.

Note that this was the only case that the second-phase material ctched black, suggesting the presence of a palladum-yttrum compound. 

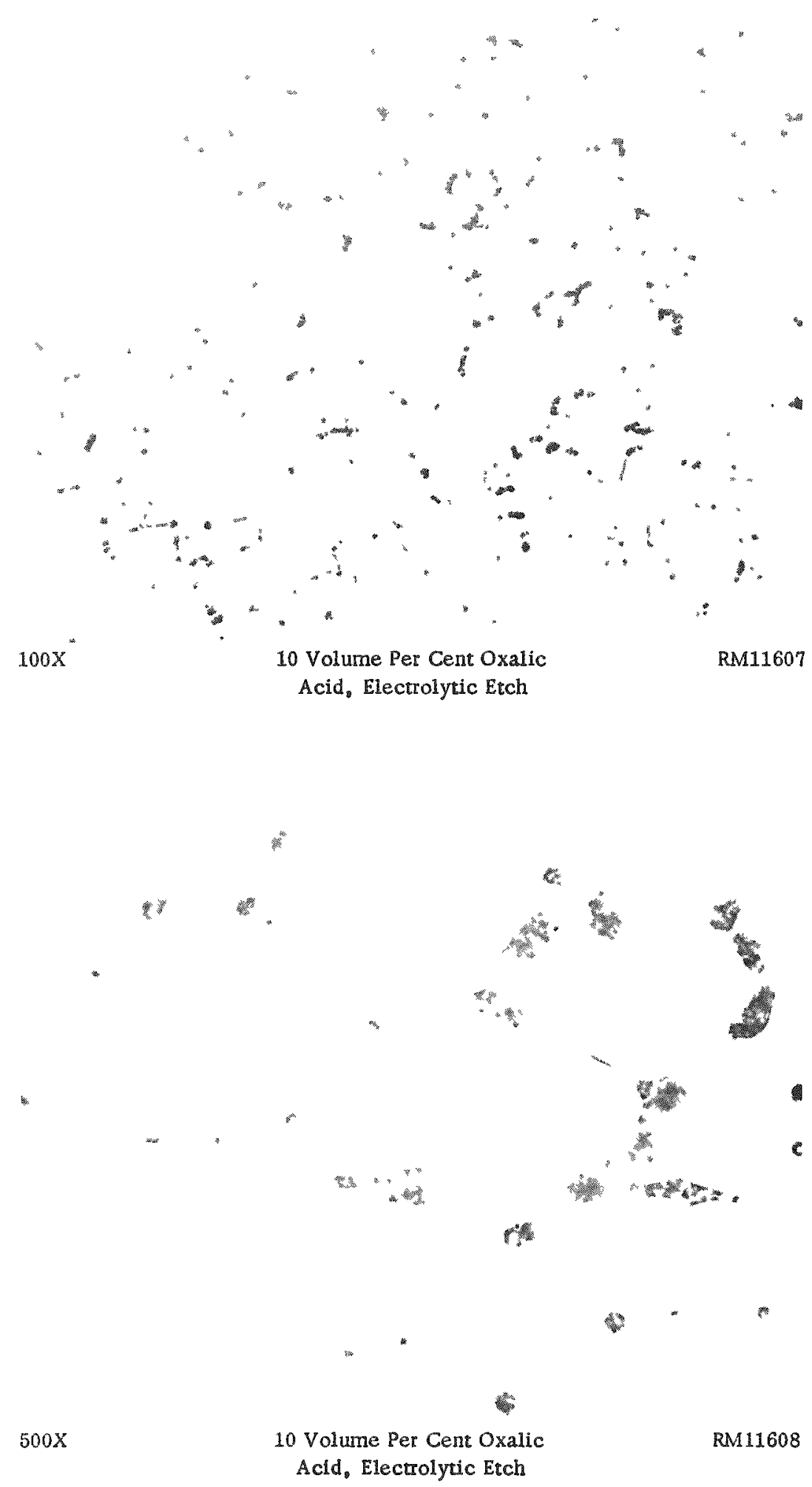

FIGURE 8. AS-CAST SECTION OF INGOT WITH CARBON ADDED

Alloy composition: iron-35 $\mathrm{w} / \mathrm{o}$ chronium-1.07 $\mathrm{w} / 0$ yrtrium -0.08 w/o carbon.

Carbon appears to be present as agglomerations of platelets. 


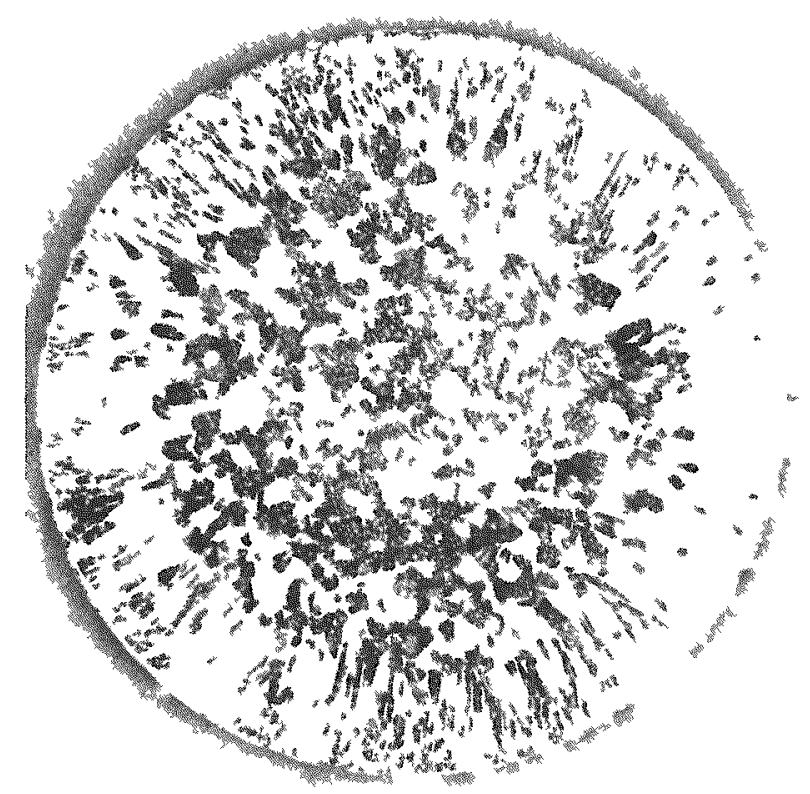

$3 x$

a. Macroctched Section

RM111648

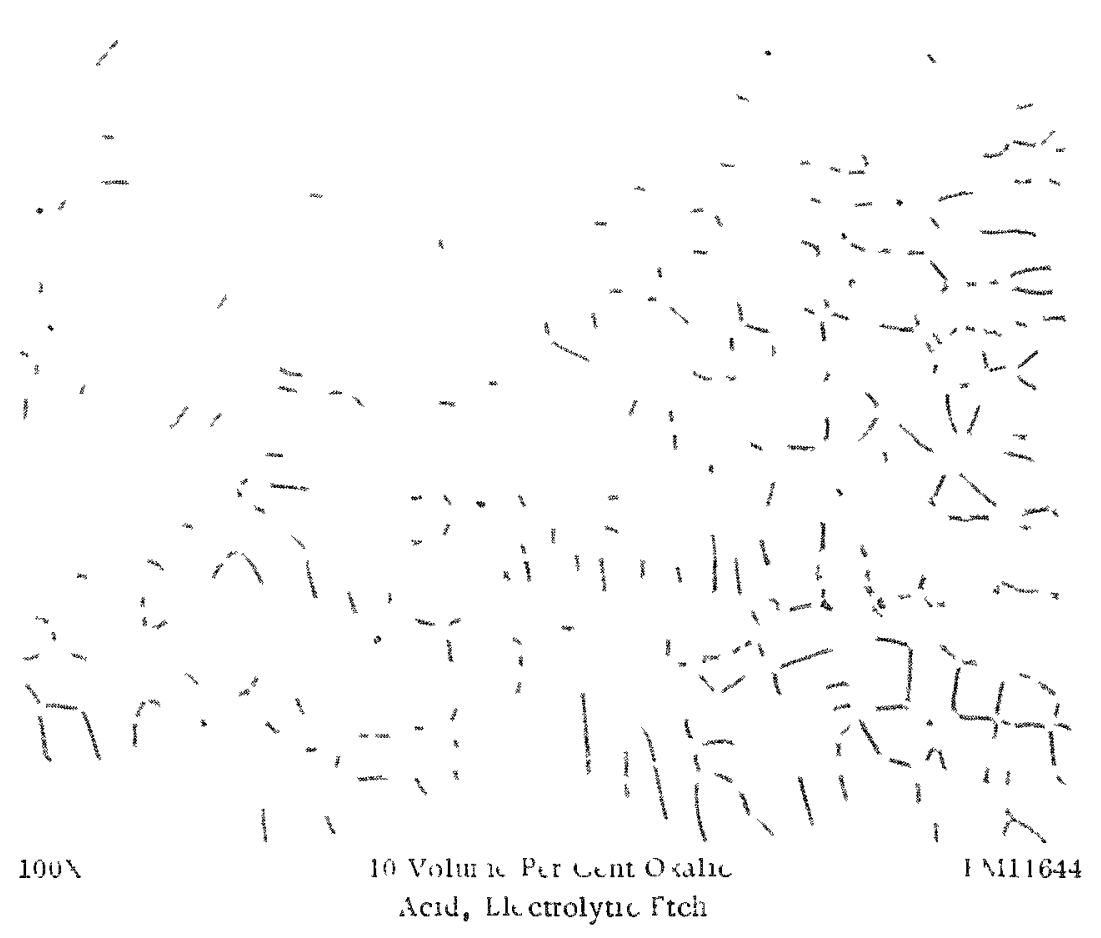

b. Nitro tructure of Center of Ingot

FIGURE 3. AS-CAST SECTIONS OF INGOT WITH CARBON ADDITION CAST IN COPPER MOLD INMTEAD OF ZIRCONITE

Alloy composition. iron-35 w, o chromum $-1.38 \mathrm{w} /$ o y tirum $-0.08 \mathrm{w}, \mathrm{o}$ carbon. Rapid chlling of the heat pitrited the precipitation of carbon. 


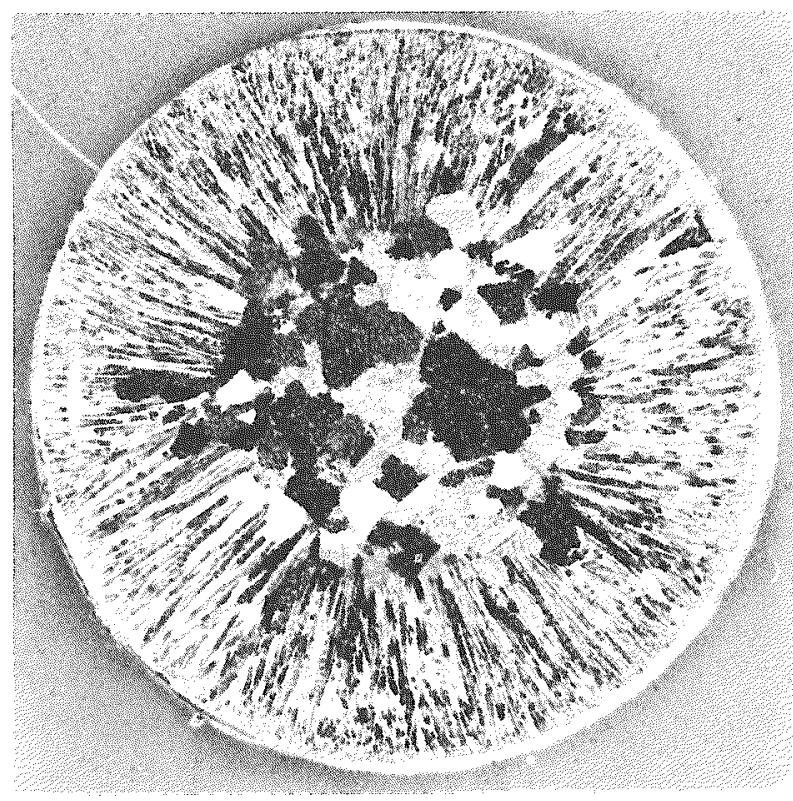

$3 x$

RM11649

FIGURE 10. MACROETCHED SECTION OF CONTROL ALLOY CAST IN COPPER MOLD

Alloy composition: iron $-35 \mathrm{w} / \mathrm{o}$ chromium $-1.08 \mathrm{w} / \mathrm{o}$ ytrium.

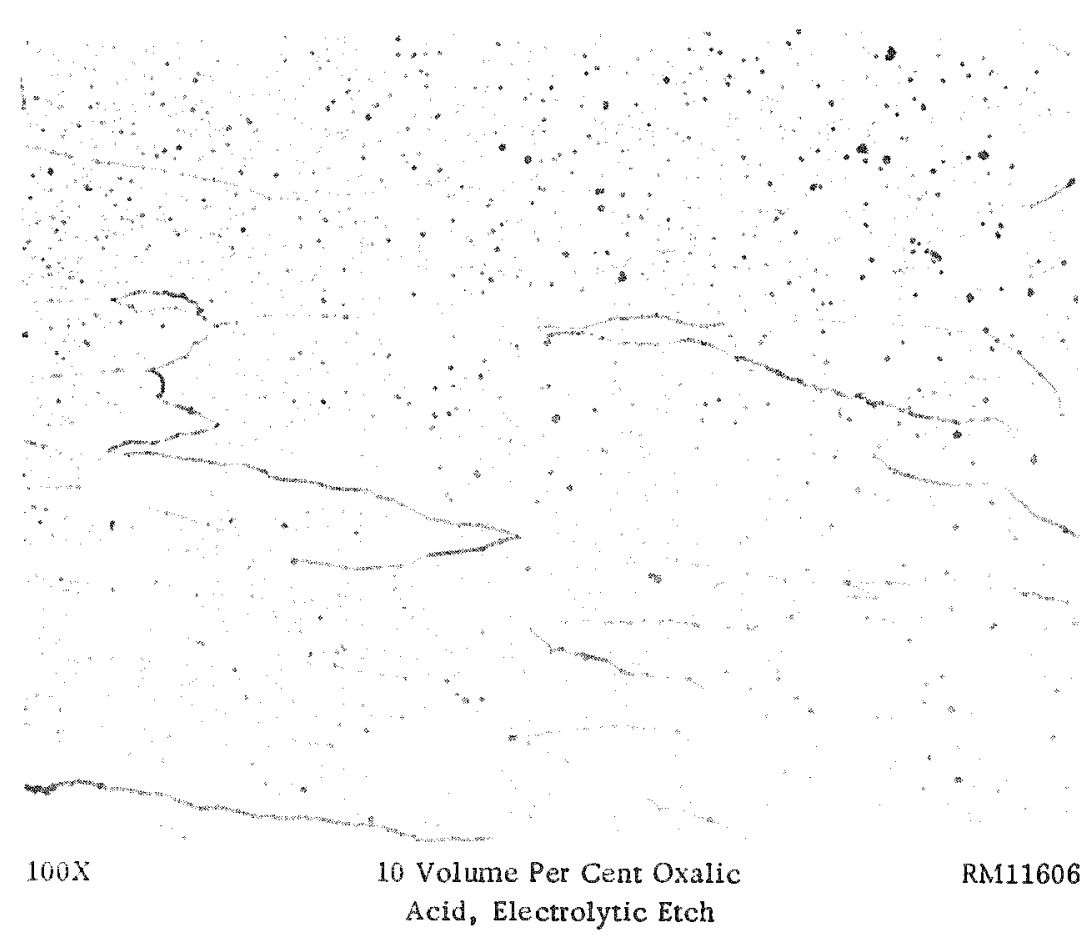

FIGURE 11. AS-CAST SECTION OF INGOT ARC MELTED WITH Fe, $\mathrm{O}_{3}$

Alloy composition: iron $-35 \mathrm{w} / \mathrm{o}$ chromium $-0.12 \mathrm{w} / \mathrm{o}$ oxygen.

Iron oxide reacted directly with the yttrium contained in the initial alloy. 
TABLE 2. FABRICATION OBSERVATIONS

\begin{tabular}{|c|c|c|c|c|c|}
\hline Alloy Addirion & $\begin{array}{c}\text { Amount } \\
\text { Retained, W/o }\end{array}$ & $\begin{array}{c}\text { Observations } \\
\text { During Hot Rollíng of } \\
0.050-\text { In. Sheet }\end{array}$ & Rating(a) & $\begin{array}{c}\text { Observations } \\
\text { During Cold Rolling of } \\
0.003-\text { In. Foil }\end{array}$ & Raung(a) \\
\hline None, master alloy & - & $\begin{array}{l}\text { Very slight edge } \\
\text { cracking }\end{array}$ & 2 & - & -- \\
\hline None, control alloy & - & $\begin{array}{l}\text { Sawtooth }\left(1 / 16-\text { in. }_{0}\right) \\
\text { edges }\end{array}$ & 4 & Blistered at edges & 3 \\
\hline Manganese & $0.23 \mathrm{Mn}$ & Slight edge cracking & 3 & $\begin{array}{l}\text { Extensive surface } \\
\text { blistering }\end{array}$ & 4 \\
\hline Iron sulfide No. 1 & $0.008 \mathrm{~s}$ & $\begin{array}{l}\text { Very slight edge } \\
\text { cracking }\end{array}$ & 2 & Very slight blistering & 1 \\
\hline Sulfur-manganese & $\begin{array}{l}0.008 \mathrm{~s} \\
0.19 \mathrm{Mn}\end{array}$ & No edge cracks & 1 & Very slight blistering & 1 \\
\hline Iron sulfide No. 2 & $0.012 \mathrm{~s}$ & No edge cracks & 1 & Slught blisternng & 2 \\
\hline Palladium & $0.83 \mathrm{Pd}$ & No edge cracks & 1 & Slight blistering & 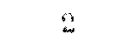 \\
\hline Iron carbide & $0.08 \mathrm{C}$ & $\begin{array}{l}\text { Very slight edge } \\
\text { cracking }\end{array}$ & 2 & Slight blusterng & $\therefore$ \\
\hline Iron oxide & 0.120 & No edge cracks & 1 & Blistering at center (b) & 3 \\
\hline None, control alloy $(c)$ & -- & Slight edge cracking & 3 & Slight blistering & 2 \\
\hline Iron carbide(c) & $0.08 \mathrm{C}$ & Slight edge cracking & 3 & Severe blisterng & 4 \\
\hline
\end{tabular}

(a) Ratings give the order of quality of surfaces and edges, e.g. , No. 1 was highest quality.

(b) Rolling of this alloy was stopped at $0.010 \mathrm{in}$.

(c) Cast in copper molds. 
yttrium and the oxygen content was $1200 \mathrm{ppm}$. The as-cast structure (Figure 11) showed long columnar grains, typical of an arc-melted bar casting. A fine dispersion of foreign matter, possibly $\mathrm{X}_{2} \mathrm{O}_{3}$, was observed in the matrix.

All ingots were forged and rolled at $2000 \mathrm{~F}$ to 0.050 -in. sheet. A small section of the resultant sheet from each ingot was subsequently cold rolled at room temperature to $3-\mathrm{mil}$ foil as a qualitative measure of ductility and metal soundness. When present, voids and solid inclusions in the metal produced exaggerated surface defects in the foil. A summary of the fabrication data is shown in Table 2. All ingots produced during this program fabricated to sheet of good quality. However, the surface appearance of the cold rolled, $3-\mathrm{mil}$ foil produced from the manganese alloy gave evidence of several internal voids. The ingots containing $80 \mathrm{ppm}$ sulfur and $800 \mathrm{ppm}$ carbon gave indications of slightly lower ductility than the control alloy during cold fabrication. The ingot containing added oxygen appeared harder than any of the others during cold fabrication and rolling was discontinued at a thickness of $0.010 \mathrm{in}$.

\section{CONCLUSIONS}

This study of the effect of impurities on the iron $-35 \mathrm{w} / 0$ chromium-1 w/o yttrium alloy has shown that under the melting, casting, and fabrication conditions imposed none of the impurities investigated affect fabrication characteristics to any major extent. Large amounts of oxide and carbide slightly decreased the ductility of the sheet. Fabrication of master alloys produced indications that variations in yttrium content up to $2 \mathrm{w} / \mathrm{o}$ do not affect fabrication characteristics adversely. The excellent fabrication characteristics displayed by the master alloy and by the products of successive remelts suggest that other melting and fabrication parameters such as pouring temperature and ingot size, perhaps in conjunction with certain combinations of impurities, should be investigated to produce a better understanding of fabrication inconsistencies of production-size ingots.

It was found that oxygen and sulfur contamination introduced before or during melting affects the amount of yttrium that will be retained in the alloy. Attempts to build up the sulfur content of the iron $-35 \mathrm{w} / 0 \mathrm{chromium}-1 \mathrm{w} / 0$ yttrium alloy indicated a maximum tolerance of between 80 and $120 \mathrm{ppm}$. 